\title{
Linking Soil Conservation in Potato Production Systems in the Highlands of Southwestern Uganda to Gender and Farmer-Market Types
}

\author{
Robert Muzira' ${ }^{1}$ John Steven Tenywa ${ }^{2}$, Twaha Basamba ${ }^{2}$ \\ ${ }^{1}$ National Agricultural Research Organization, Kampala, Uganda \\ ${ }^{2}$ Makerere University, Kampala, Uganda \\ Email:nrmuzira@yahoo.com
}

How to cite this paper: Muzira, R., Tenywa, J.S. and Basamba, T. (2018) Linking Soil Conservation in Potato Production Systems in the Highlands of Southwestern Uganda to Gender and Farmer-Market Types. Open Access Library Journal, 5: e4422.

https://doi.org/10.4236/oalib.1104422

Received: February 12, 2018

Accepted: April 15, 2018

Published: April 18, 2018

Copyright $\odot 2018$ by authors and Open Access Library Inc.

This work is licensed under the Creative Commons Attribution International License (CC BY 4.0).

http://creativecommons.org/licenses/by/4.0/

\begin{abstract}
Rural communities in sub-Saharan Africa develop different livelihood strategies driven by opportunities and constraints encountered in existing biophysical and socioeconomic environments. A study on gender effects under two market linkages on investments in soil conservation innovations in potato production systems was conducted in the highlands of southwestern Uganda. There were significant differences in land size under fallow belonging to Male Headed Households (MHHs) and Female Headed Households (FHHs) with urban and non-urban market linkages $(\mathrm{p}<0.05)$. None the less both FHHs and MHHs had more land under fallow. This was attributed to the trainings farmers obtained in the control of bacterial wilt of potato through integrating fallow period in the potato cropping systems. Under urban and non-urban market linkages, there were no significant differences in percentage distribution of potato fields for MHHs and FHHs without soil conservation structure $(p>0.05)$. This was attributed to limited land holdings owned by farmers that are intensively cultivated.
\end{abstract}

\section{Subject Areas}

Soil Science

\section{Keywords}

Socioeconomic, Soil Conservation, Gender, Market Linkages

\section{Introduction}

There is no single resource more important in achieving sustainable agricultural production than the soil, which contains soil nutrients and water that support 
plant growth [1]. The conventional way of improving agricultural productivity is done by applying chemical fertilizers to improve soil fertility and using high yielding variety seeds [2]. There is ample evidence from experience outside Africa that increased use of inorganic fertilizers has been responsible for an important share of world-wide agricultural productivity growth [3]. On the other hand, the gross average rate of fertilizer application in Uganda is about $1 \mathrm{~kg}$ of nutrients/ha, which is among the lowest in the world [4]. Due to low soil amendments accompanied with continuous cultivation, soil fertility mining is on high rate and wide scale leading to declining crop yields [5]. It is estimated that nutrients in Uganda are depleted at an annual average rate of $38 \mathrm{~kg}$ of Nitrogen (N), $17 \mathrm{~kg}$ of Phosphorus (P) and $32 \mathrm{~kg}$ of Potassium (K) per hectare [6]. Adoption of "improved" integrated nutrient management practices generally has been poor due to various factors such as high costs of technologies, lack of markets for produce and farmers' lack of knowledge about soil conservation methods [7]. Population pressure on the other hand, leads to land fragmentation, which decreases the per capita farm size [8]. The average per capita area of cropland in Uganda is 0.34 ha with southwestern region having the smallest per capita cropland area [9]. Land degradation and rural poverty are interrelated challenges in agricultural production [10] with consequences most felt by the poor especially women who depend on agriculture-related activities for their livelihoods.

The increasing interest in the market orientation and special programs like African Growth and Opportunity Act (AGOA) and New Partnership for Africa Development (NEPAD) offers new opportunities for smallholder farmers in developing countries to alleviate poverty. This is great opportunity for the poor, and especially for poor women producers who rely on the intensification of subsistence and cash cropping on the land they cultivate. To increase household incomes and rural livelihoods, Uganda Government started special programs such as "plan for agricultural modernization" and "prosperity for all". In these programs farmers are urged to embrace new technologies and produce commodities for market.

On the account of government's call, International Centre for Tropical Agriculture (CIAT) in partnership with Africare-Uganda trained farmers in the highlands of south-western Uganda in improved soil conservation innovations for potato production. The trained farmer groups later linked to urban markets with the hypothesis that after getting practical skills in soil conservation and linking to profitable markets, part of the proceeds will be invested in soil conservation. Hence, this paper examines, gender analysis in investments in soil conservation innovations among farmers with urban and non-urban market linkages.

\section{Methodology}

\subsection{Study Area and Characteristics of Farming System}

The study was conducted in 2015 in Kamuganguzi Sub County which is found in 
Kabale district in southwestern Uganda. Kabale district is located at $1.35^{\circ} \mathrm{S}$ and $30.02^{\circ} \mathrm{E}$ with relief that ranges between 1791 and 2000 meters above sea level. It has a population of 50,312 in radius of $7 \mathrm{~km}$ [11]. The rainfall pattern is similar to that of the district in general. It has bimodal rainfall of $1800 \mathrm{~mm}$ per year on average. The first rains are in March-May and are considered to be short while the second rains which are long occur in September-January. A major dry season occurs during June-August while rainfall peaks are in April and November [12]. The soils on hill slopes are ferralitic in nature having low $\mathrm{pH}$ and productivity while most valleys have Histosols with thick top soil that contains high organic matter. Soils in the valleys have medium to high productivity due to abundant organic matter [12].

\subsection{Site Selection and Farmer Organization}

Six parishes with similar biophysical characteristics and cropping pattern details in Kamuganguzi Sub County were selected for this study. Three parishes ( $B u$ ranga, Katenga and Kicumbi) had farmers organized in groups, trained in soil conservation under potato production and linked to urban markets. These groups comprised of 50 and 70 female headed households (FHHs) and male headed households (MHHs). On the other hand, farmers with non-urban market linkages had no formidable groups and social capital. Farmers with non-urban market linkages, had limited knowledge and skills in soil conservation and sold potato produce through brokers.

\subsection{Farm Selection and Rapid Characterization}

Approximately 10 key informants that included community leaders and elders having wide knowledge about well being of fellow farmers were invited in the Focus Group Discussions (FGDs). During FGDs, farmers generated lists of households that were stratified according to Wealth Categories (WCs) following criteria developed by farmers (Table 1). A total of 120 households, who had gone through project activities; and 227 households that had not been in the project but growing potato for non-urban markets were selected for the study using attendance and community residence lists, respectively.

The interview targeted both male and female headed households though in male headed households, women were also interviewed to clarify some issue since they spent most of their time in the fields and could understand the history of each plot very well. A plan was drawn showing the location of each plot in the community to enhance identity of homestead. In this survey, households were confirmed or reallocated to correct WCs through field walks and using integrated information generated from the FGDs.

\subsection{Statistical Analysis}

The information derived from the semi-structured interviews was expressed as average values for socio economic indicators (e.g. mean number of plots under 
Table 1. Farmers' own criteria of categorizing different households.

\begin{tabular}{|c|c|c|c|c|}
\hline Farmers' criteria & Class I & Class II & Class III & Class IV \\
\hline $\begin{array}{c}\text { Nature of the } \\
\text { house }\end{array}$ & $\begin{array}{l}\text { Good and } \\
\text { permanent }\end{array}$ & $\begin{array}{l}\text { Good but semi } \\
\text { permanent }\end{array}$ & $\begin{array}{l}\text { Mostly grass } \\
\text { thatched }\end{array}$ & $\begin{array}{l}\text { Mostly small and } \\
\text { grass thatched }\end{array}$ \\
\hline $\begin{array}{l}\text { Means of } \\
\text { transport }\end{array}$ & $\begin{array}{l}\text { Vehicle or } \\
\text { bicycle }\end{array}$ & Bicycle & Mostly foot & Mostly foot \\
\hline $\begin{array}{l}\text { Possession of } \\
\text { money (USD) }\end{array}$ & $1571-2619$ & $104-523$ & $10-26$ & $0-2$ \\
\hline No. of plots & $15-100$ & $10-14$ & $2-4$ & $\leq 2$ \\
\hline $\begin{array}{l}\text { Heads of } \\
\text { cattle }\end{array}$ & $4-10$ & $1-3$ & None & None \\
\hline $\begin{array}{l}\text { No. of small } \\
\text { ruminants }\end{array}$ & $10-20$ & $2-10$ & 1 & None \\
\hline $\begin{array}{c}\text { No. of } \\
\text { woodlots }\end{array}$ & $3-5$ & $1-2$ & None & None \\
\hline $\begin{array}{l}\text { Children's } \\
\text { education }\end{array}$ & $\begin{array}{c}\text { In boarding } \\
\text { schools }\end{array}$ & $\begin{array}{l}\text { Good day } \\
\text { schools }\end{array}$ & $\begin{array}{l}\text { Universal } \\
\text { education }\end{array}$ & None \\
\hline No. of workers & $30-50$ & $5-20$ & None & None \\
\hline $\begin{array}{c}\text { No. of meals } \\
\text { taken }\end{array}$ & 4 & 2 & 1 & 1 \\
\hline $\begin{array}{c}\text { Use of soil } \\
\text { amendments }\end{array}$ & $\begin{array}{l}\text { FYM and } \\
\text { fertilizers }\end{array}$ & $\begin{array}{l}\text { FYM and } \\
\text { fertilizers }\end{array}$ & FYM & None \\
\hline $\begin{array}{l}\text { Potato yields } \\
\text { (No of bags) }\end{array}$ & $100-500$ & $10-50$ & $2-5$ & 1 \\
\hline
\end{tabular}

cultivation in different households) and percentage distribution (Distribution of plots under potato) by tallying and using ANOVA table of Genstat Release 6.

\section{Results and Discussion}

\subsection{Demographic Characteristics of the Respondents}

The proportion of households in parishes with and without urban market linkages involved in potato production was $41.3 \%(\mathrm{n}=242)$ and $47.9 \%(\mathrm{n}=288)$, respectively. Socio-economic characteristics such as age, education, nature of the main residential house, marital status, gender and household size are known to have impact and influence on the way of thinking, attitudes and perceptions and behavior towards adoption of agricultural innovations [13]. Results indicated that ages of the majority of the household heads ranged between 40 and 55 years. The age bracket of 40 - 55 years had the majority of farmers, $36.8 \%$ and $43.6 \%$ with urban and non-urban market linkages respectively. Nonetheless, the distribution of farmers in both market linkages was skewed towards the young (Table 2). This was because young farmers often had to take risks as opposed to older farmers [14].

The majority of the main residential houses in the homesteads for farmers with urban and non-urban market linkages were semi-permanent. The distributions of nature of residential main houses for farmers under both market 
Table 2. Socio-economic characteristics of potato farmers.

\begin{tabular}{|c|c|c|}
\hline Parameter & $\begin{array}{l}\text { Urban market } \\
\text { linkages (\%) }\end{array}$ & $\begin{array}{c}\text { Non-urban market } \\
\text { linkages (\%) }\end{array}$ \\
\hline \multicolumn{3}{|l|}{ Age of the household head } \\
\hline From 20 to 39 & 34.7 & 28.2 \\
\hline From 40 to 55 & 36.8 & 43.6 \\
\hline From 56 to 69 & 16.3 & 15.4 \\
\hline From 70 to 98 & 15.7 & 15.2 \\
\hline STD & 11.4 & 13.4 \\
\hline \multicolumn{3}{|l|}{ Residential main house } \\
\hline Grass-thatched & 3.9 & 15.2 \\
\hline Semi-permanent & 80.4 & 76.1 \\
\hline Permanent & 15.7 & 8.7 \\
\hline STD & 41.18 & 37.17 \\
\hline \multicolumn{3}{|l|}{ Gender of household head } \\
\hline Male & 62.7 & 71.7 \\
\hline Female & 37.3 & 23.3 \\
\hline STD & 18.0 & 30.7 \\
\hline \multicolumn{3}{|l|}{ Marital status } \\
\hline Single & 4.8 & 0.0 \\
\hline Married & 47.6 & 33.3 \\
\hline Widowed & 47.6 & 66.7 \\
\hline STD & 24.7 & 33.3 \\
\hline \multicolumn{3}{|c|}{ Education level of household head } \\
\hline Lack formal education & 44.0 & 44.4 \\
\hline Primary & 52.0 & 42.2 \\
\hline Secondary & 4.0 & 13.3 \\
\hline STD & 25.72 & 17.4 \\
\hline \multicolumn{3}{|l|}{ Household size } \\
\hline From 0 to 4 & 43.1 & 39.1 \\
\hline From 5 - 10 & 51.0 & 56.5 \\
\hline Above 10 & 5.9 & 4.3 \\
\hline STD & 24.1 & 26.6 \\
\hline
\end{tabular}

linkages were skewed towards permanent and grass-thatched houses respectively. Higher distribution of grass-thatched main houses (15.2\%) was found with farmers under non-urban marker linkages. Under non-urban markets linkages $71.7 \%$ of the households were male headed as opposed to those with urban market linkages (62.7\%). Nonetheless, households with non-urban market linkages had higher proportion of farmers who were widowed (67\%). On the other hand, 
there were equal proportions of households under urban market linkages with married and widowed farmers.

More than $50 \%$ of the households with urban market linkages had primary education. On the other hand, majority of the household heads with non-urban market linkages (44.4\%) had no formal education. Low proportion of household heads had secondary education regardless of the type of market linkages.

Majority of households had family size that ranged from 5 to 10 people, with households with non-urban market linkages exhibiting a higher proportion (56.5\%). Households with less than five members were $43.1 \%$ and $39.1 \%$ under urban and non-urban market linkages, respectively. Likewise households with more than 10 members were $5.9 \%$ and $4.3 \%$ under urban and non-urban market linkages, respectively.

\subsection{Distribution of Gendered farm Land Use and Abandoned Fields among Households}

Other than fallowed land, FHHs had less land under cultivation and woodlots compared to MHHs with urban market linkages (Figure 1). This is because FHHs had fewer resources such as labor to put much of farmland under cultivation resulting into large acreage of land fallowed as compared to MHHs. Limited land for potato production was the major constraint among farmers in the highlands of south-western Uganda [15]. The FHHs are resource constrained in form of labor and capital to hire farm labor, and hence opened up limited land compared to the MHHs. More households with urban market linkages solely depended on potato production and MHHs with resources hired more land from other households to increase volumes of potato yields. Farmers with non-urban market linkages placed less land under cultivation.

This was because most of these farmers thrived on cross boarder business as alternative source of income. Large acreage of land under woodlots was found with MHHs with urban and non-urban market linkages. Households with urban market linkages had more land under woodlots compared to their counterparts with non-urban market linkages. This was because households with non-urban market linkages had alternative source income from cross-border business and placed more land under woodlots as a way of long term investment and land security.

Abandoned land was regarded as unproductive by farmers and was characterized by shallow soils, rocky outcrops, gullies and low soil fertility due to erosion as reported by [16]. This land was often found on steep slopes (>75\%). It was the FHHs with urban market linkages that had the least amounts of abandoned land. This was because FHHs with urban market linkages had less land and most of if it was located near homesteads. Such land near homesteads was more accessible by household members. It was also more fertile because it received more inputs in form of farmyard manure and household wastes. Under smallholder farming systems with low soil input management systems, soil fertility gradually reduces as distances from homesteads increase as reported by [17]. 
Cultrvated land

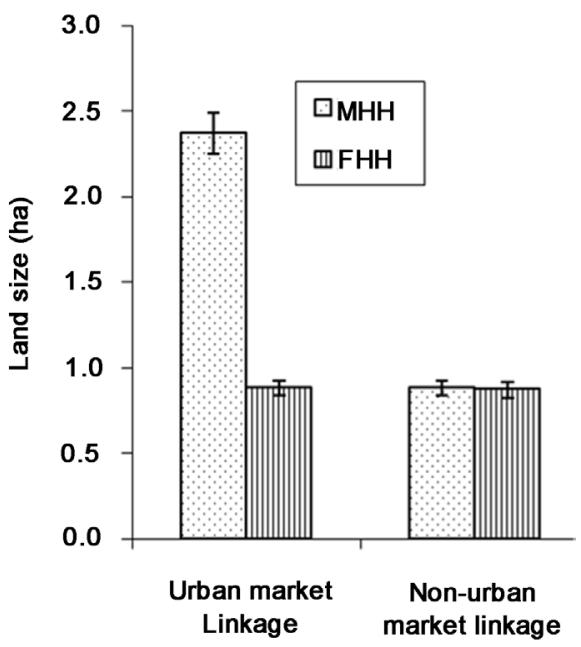

(a)

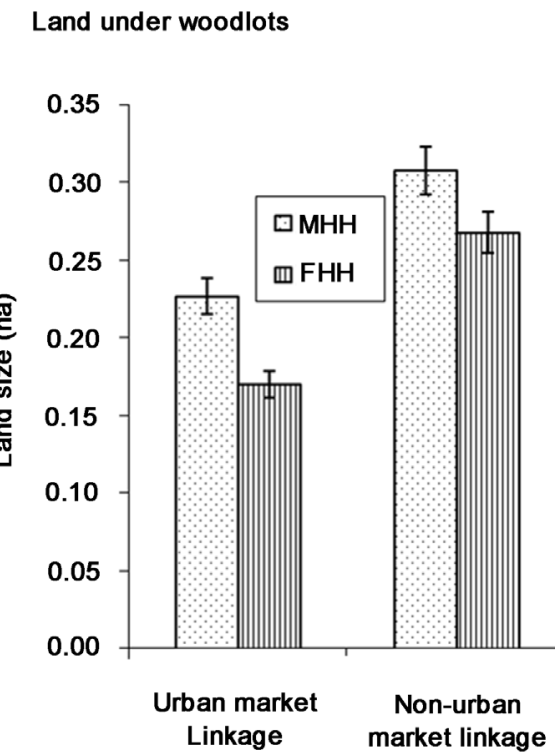

(c)
Fallowed land

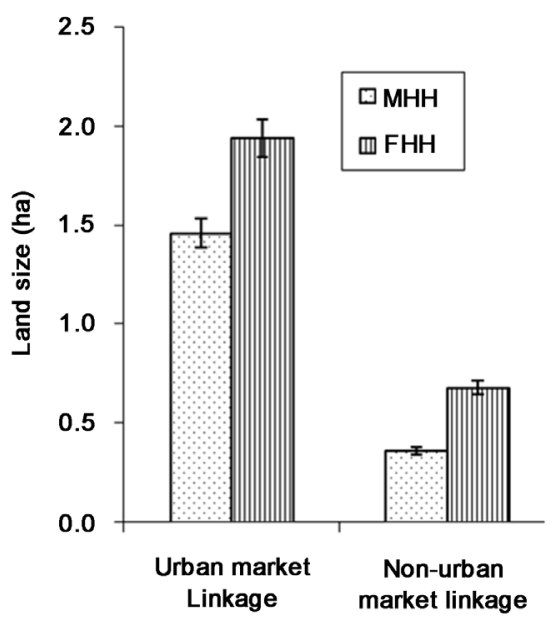

(b)

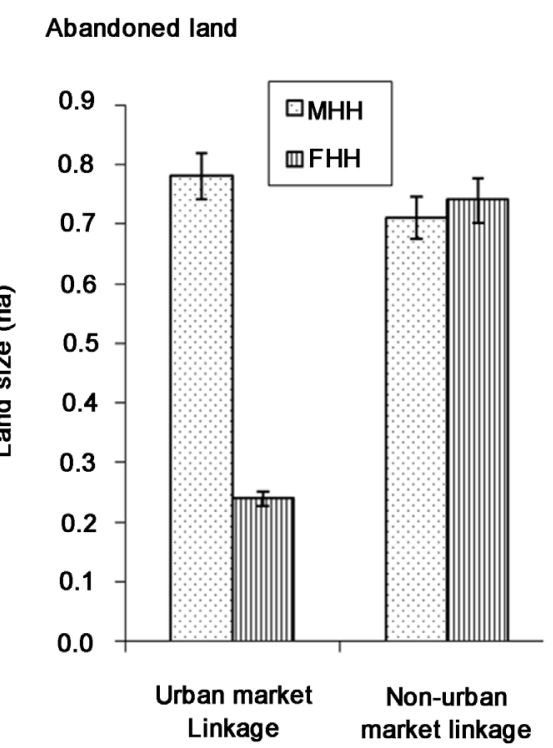

(d)

Figure 1. Gendered variations in land use among household under urban and non-urban market linkages.

\subsection{Farmers' Investments in Soil Conservation Innovations}

Uncontrolled soil erosion was the major cause of land degradation in potato fields in the highlands of south-western Uganda. This was because over $80 \%$ of potato fields for MHHs and FHHs had no soil conservation measures, regardless of market linkage types (Figure $2 \&$ Figure 3). Farmers under both market linkages had widely destroyed soil conservation measures that were once constructed during colonial era [18].

High population pressure and poverty were considered as one of the leading factors in causing land degradation in the highlands of south-western Uganda [19]. 


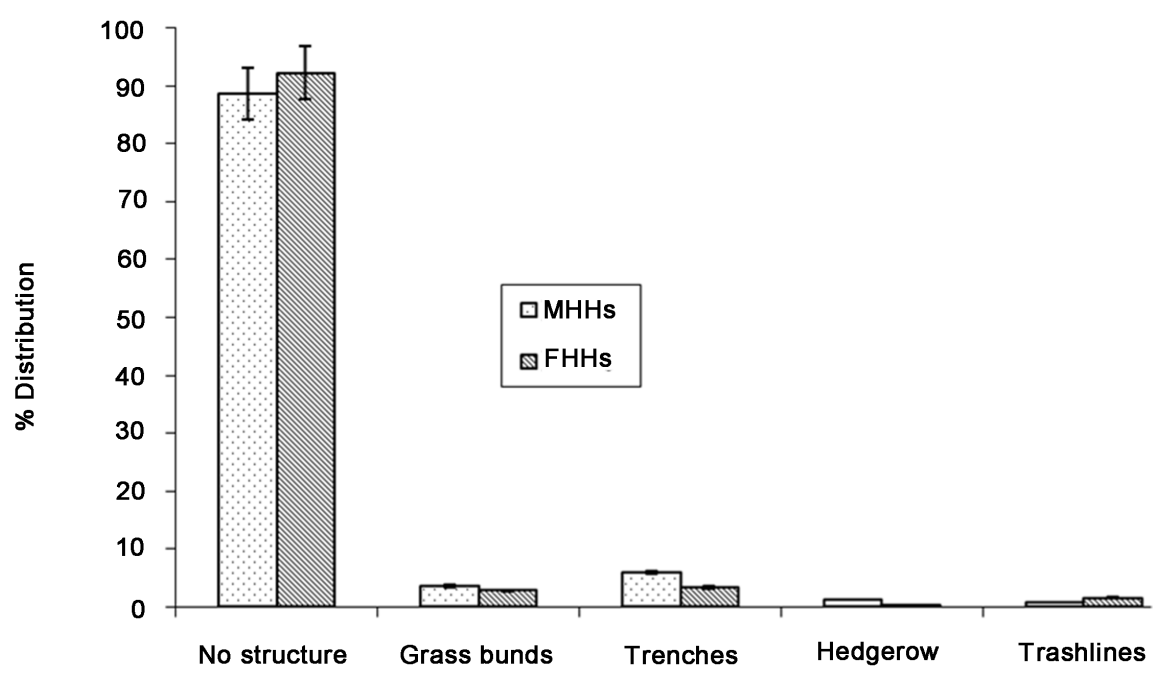

Figure 2. Gendered distribution of potato fields under urban market linkages with different soil conservation innovations.

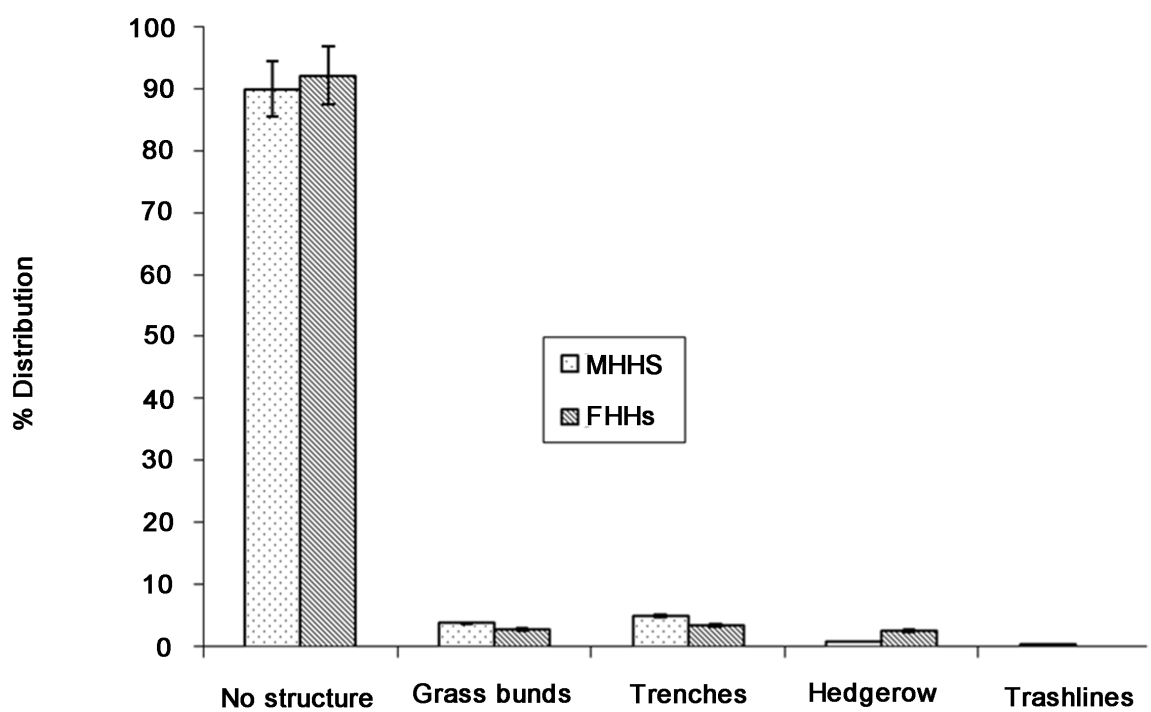

Figure 3. Gendered distribution of potato fields under non-urban market linkages with different soil conservation innovations.

Though destruction of soil conservation structures was high with households having urban and non-urban market linkages, it was the FHHs that had higher proportions of potato fields with destroyed soil conservation structures. This was attributed to the reduced soil fertility in potato fields owned by FHHs forcing them to extend the area of cultivation to the edge of the fields. Furthermore, poverty among FHHs led to individual farmers to hire out some of the fields to other farmers who destroyed soil conservation structures to expand cultivated area.

\section{Conclusion}

Linking farmers in the highlands of south-western Uganda to urban markets 
stimulated potato production through farmers opening up more land compared to those under non-urban market linkages. The MHHs under urban market linkages opened up more land compared to the FHHs because of the differences in ownership of resources by gender. Linking farmers to urban markets did not stimulate soil conservation among the MHHs and FHHs, which led to further land degradation in potato fields.

\section{Acknowledgements}

The authors would like to acknowledge The Belgium Technical Cooperation (BTC) and International Center for Tropical Agriculture (CIAT) for funding the study. Sincere thanks go to farmers in the highlands of south-western Uganda for their invaluable time accorded to this study. Also appreciation goes to Dr. Gracious Diiro for his invaluable time to improve the thesis from which this paper was extracted.

\section{References}

[1] Chikowo, R., Corbeels, M., Mapfumo, P. and Tittonell, P. (2010) Nitrogen and Phosphorus Capture and Recovery Efficiencies, and Crop Responses to a Range of Soil Fertility Management Strategies in Sub-Saharan Africa. Nutrient Cycling in Agroecosystems, 88, 59-77. https://doi.org/10.1007/s10705-009-9303-6

[2] Svubure, O., Struik, P.C., Haverkort, A.J. and Steyn, J.M. (2015) Yield Gap Analysis and Resource Footprints of Irish Potato Production Systems in Zimbabwe. Field Crops Research, 178, 77-90. https://doi.org/10.1016/j.fcr.2015.04.002

[3] Seck, A. (2017) Fertiliser Subsidy and Agricultural Productivity in Senegal. The World Economic Forum, 40, 1989-2006. https://doi.org/10.1111/twec.12487

[4] Kaizzi, K.C., Byalebeka, J., Semalulu, O., Alou, I., Zimwanguyizza, W., Nansamba, A., Musinguzi, P., Ebanyat, P., Hyuha, T. and Wortmann, C.S. (2012) Maize Response to Fertilizer and Nitrogen Use Efficiency in Uganda. Agronomy Journal, 104, 73-82. https://doi.org/10.2134/agronj2011.0181

[5] do Carmo, F.F. and Jacobi, C.M. (2016) Diversity and Plant Trait-Soil Relationships among Rock Outcrops in the Brazilian Atlantic Rainforest. Plant Soil, 403, 7-20. https://doi.org/10.1007/s11104-015-2735-7

[6] Vanlauwe, B., Van Asten, P. and Blomme, G. (Eds.) (2014) Challenges and Opportunities for Agricultural Intensification of the Humid Highland Systems of Sub-Saharan Africa. Springer, Switzerland.

[7] Buyinza, J., Sekatuba, J., Agaba, H., Kinuthia, R. and Kiptot, E. (2015) Analysis of Extension Systems in Uganda for Identification of Suitable Extension Approaches for Scaling-Up 'Trees for Food Security'. Project in Eastern Uganda ACIAR 'TREES FOR FOOD SECURITY’ PROJECT’.

[8] Koohafkan, P. (2011) The State of the World's Land and Water Resources for Food and Agriculture: Managing Systems at Risk.

[9] van Soesbergen, A., van Soesbergen, A., Arnell, A.P., Sassen, M. and Stuch, B. (2017) Exploring Future Agricultural Development and Biodiversity in Uganda, Rwanda and Burundi: A Spatially Explicit Scenario-Based Assessment. Regional Environmental Change, 17, 1409-1420. https://doi.org/10.1007/s10113-016-0983-6

[10] Headey, D.D. and Jayne, T.S. (2014) Adaptation to Land Constraints: Is Africa Different? Food Policy, 48, 18-33. https://doi.org/10.1016/j.foodpol.2014.05.005 
[11] Bagyenda, R., Muzira, R. and Mbabazi, P. (2003) Participatory Land Degradation Assessment in the Highlands of Kabale District, Southwestern Uganda. Annex F of the Final Technical Report for Project R7856.

[12] NEMA (2010) Environmental Sensitivity Atlas for the Albertine Graben. 2nd Edition.

[13] Okuthe, K., Kioli, F. and Abuom, P. (2013) Socio Economic Determinants of the Adoption of Integrated Natural Resource Management Technologies by Small Scale Farmers: Evidence from Western Kenya. Journal of Environmental and Earth Sciences, 5, 481-496.

[14] Mukindia, B.M. (2014) Influence of Collective Action on Market Access among Smallholder Banana Farmers in Imenti South District, Kenya. International Journal of Project Management, 1, 99-110.

[15] Dawson, N., Martin, A. and Sikor, T. (2016) Green Revolution in Sub-Saharan Africa: Implications of Imposed Innovation for the Wellbeing of Rural Smallholders. World Development, 78, 204-218.

https://doi.org/10.1016/j.worlddev.2015.10.008

[16] Adekunle, A.A., Fatunbi, A.O., Buruchara, R. and Nyamwaro, S. (2013) Integrated Agricultural Research for Development: From Concept to Practice. Forum for Agricultural Research in Africa FARA.

[17] Nezomba, H. (2015) Sequencing Integrated Soil Fertility Management Options for Sustainable Crop Intensification by Different Categories of Smallholder Farmers in Zimbabwe. Experimental Agriculture, 51, 17-41.

https://doi.org/10.1017/S0014479714000131

[18] Muzira, R., Vanlauwe, B., Rwakaikara, S.M., Basamba, T., Chianu, J. and Farrow, A. (2011) Innovations as Key to the Green Revolution in Africa: Exploeing the Scientifc Facts. In: Bationo, A., et al., Eds., Innovations as Key to the Green Revolution in Africa, Springer Science+Business Media B.V., 1414.

[19] Andersson, E. (2014) Turning Waste into Value: Using Human Urine to Enrich Soils for Sustainable Food Production in Uganda. Journal of Cleaner Production, 96, 290-298. https://doi.org/10.1016/j.jclepro.2014.01.070 